\title{
Feed Intake, Growth Performance and Blood Constituents of Growing Male West African Dwarf Goats Fed Concentrates Varying in Pueraria phaseoloides Leaf Meal Content
}

\author{
Abel Adebayo Akingbade ${ }^{*}$, Paul Shinngu', Kayode Jacob Onaleye ${ }^{1}$, \\ Aderibigbe Ezekiel Adebiyi' ${ }^{2}$, Christianah Adifagberu² \\ ${ }^{1}$ Department Animal Production and Health, Federal University Wukari, Wukari, Nigeria \\ ${ }^{2}$ Department of Animal Production and Health, Ladoke Akintola University of Technology, Ogbomoso, Nigeria \\ Email: *akingbade abel@yahoo.com
}

Received 1 June 2015; accepted 16 August 2015; published 19 August 2015

Copyright (C) 2015 by authors and Scientific Research Publishing Inc.

This work is licensed under the Creative Commons Attribution International License (CC BY).

http://creativecommons.org/licenses/by/4.0/

(c) (i) Open Access

\section{Abstract}

The study examined feed intake, growth performance and blood constituents of growing male West African dwarf (WAD) goats fed concentrates varying in Pueraria phaseoloides leaf meal (PPLM) content. Four experimental diets that differed in PPLM content; Diets 1 (0\% PPLM), Diet 2 (10\% PPLM), Diet 3 (20\% PPLM) and Diet 4 (30\% PPLM) were fed to the WAD goats using the $4 \times 4$ Change-Over Latin Square Design in a study that lasted twelve weeks (four weeks of pre-trial acclimatization period inclusive). The trial period comprised four weeks of pre-trial acclimatization and four weeks of trial periods; with the first, second and third trials being sandwiched by two acclimatization periods; each period lasting one week. The measured parameters were fed intakes, live weights, blood proteins (total protein, albumin and globulin) and micro-mineral elements (Iron, Copper and Zinc). Crude protein contents of diets ranged between $19.24 \%$ and $20.12 \%$. Differences in treatment means of feed intakes, changes in live weights, blood proteins and micromineral elements were not significant $(p>0.05)$.

\section{Keywords}

Growth, Intake, Blood, Goats, Pueraria phaseoloides

\footnotetext{
"Corresponding author.
}

How to cite this paper: Akingbade, A.A., Shinngu, P., Onaleye, K.J., Adebiyi, A.E. and Adifagberu, C. (2015) Feed Intake, Growth Performance and Blood Constituents of Growing Male West African Dwarf Goats Fed Concentrates Varying in Pueraria phaseoloides Leaf Meal Content. Agricultural Sciences, 6, 817-822. http://dx.doi.org/10.4236/as.2015.68079 


\section{Introduction}

In tropics, goats are major source of income for farmers [1]. The main feeds of goats include: native grasses, legumes, leaves of shrubs and trees on natural grasslands. However, a major constraint to goats' productivity in Nigeria is unavailability of grass species that are adequate in quantity and quality during dry season. The consequence of this is growth retardation of the ruminants [2]. The main concern of animal scientists is adequate provision of dry season in order to prevent or reduce weight gain and loss during the season [3]. Pasture legumes and browse plants have been fed to alleviate feed constraint associated with dry season. Pueraria phaseoloides is a perennial legume; its leaves are rich in protein and this makes the legume an excellent protein supplier to ruminants when fed [4] [5]. Feeds influence blood constituents [6]-[8] and blood constituents have been used to assess health status of animals [9]. This study was aimed at examining the feed intakes, growth and haematological constituents of growing male West African dwarf (WAD) goats maintained on concentrates varying in Pueraria phaseoloides leaf meal (PPLM) content. The study will afford the opportunity of knowing the inclusion level of PPLM that will give optimum growth performance to the growing male WAD goats.

\section{Materials and Methods}

\subsection{Experimental Site}

The experimental site was Sheep and Goats Unit of Teaching and Research Farm, Ladoke Akintola University of Technology Ogbomoso. Oyo State Nigeria. Ogbomoso is located in the derived savanna zone of Nigeria and lies on $8^{\circ} 7^{\prime} \mathrm{N}$ and $4^{\circ} 15^{\prime} \mathrm{E}[10]$.

\subsection{Animals and Housing}

Four growing male West African dwarf (WAD) goats were used for the study. The goats were sourced from one of the goat markets in Ogbomoso North Local Government Area. The goats were brought to the unit and housed in separate pen; each pen had water and feed troughs. The goats were maintained on cassava peels and Gliricidia sepium during the first four weeks acclimatization period prior to the start of the study. The goats were served cassava peels and Gliricidia sepium between 08:00 and 10:00 hr daily and were drafted to graze on Panicum maximum and Pennisetum purpureum grasses around the fenced animal house between 10:00 and 16:00 hr and return to their respective pens by 16:00 hrs. Water was offered on ad libitum basis throughout the acclimatization and trial periods. The body weights of the goats at the commencement of the study were: 6.0, 7.0, 8.0 and $10.0 \mathrm{~kg}$.

\subsection{Pueraria phaseoloides Leaf Meal (PPLM) Preparation}

Fresh Pueraria phaseoloides leaves were harvested from New Pasture Introductory Unit and air dried in Pasture conservation shed for two weeks and milled using a milling machine with $1 \mathrm{~mm}$ sieve to obtain PPLM. The PPLM were bagged in ten polythene sacs and preserved pending the time of preparation of the concentrate diets.

\subsection{Experimental Diets and Experimental Design}

The feed ingredients and experimental diets are presented in Table 1; there were four experimental diets: Diet 1 (0\% PPLM); Diet 2 (10\% PPLM); Diet 3 (20\% PPLM) and Diet 4 (30\% PPLM). The diets differed in the level of Pueraria phaseoloides leaf meal (PPLM) inclusion. Pueraria phaseoloides leaf meal was used as protein feed ingredient and replaced wheat offal. The experimental design was a $4 \times 4$ Change-Over Latin Square Design (Table 2) and the study lasted twelve weeks (four weeks of pre-trial acclimatization period inclusive).

\subsection{Experimental Measurements}

\subsubsection{Feed Intake}

A known weight of the experimental diets was offered to the group of goats via the respective feed trough between 07:30 and 08:00 hr daily. The goats were allowed unrestricted access to the diets till 10:00 hrs when they were drafted to graze on Panicum maximum and Pennisetum purpureum grasses around the fenced animal house till 16:00 hr before the goats were returned to their respective pens to continue feeding on the concentrate diets in 
Table 1. Feed ingredients and experimental diets.

\begin{tabular}{|c|c|c|c|c|}
\hline Feed ingredients & Diet 1 (0\% PPLM) & Diet 2 (10\% PPLM) & Diet 1 (20\% PPLM) & Diet 1 (30\% PPLM) \\
\hline PPLM & - & $2.5(1.76)$ & $5.0(3.52)$ & $7.5(5.28)$ \\
\hline Maize bran & $4.0(1.76)$ & $4.0(1.76)$ & $4.0(1.76)$ & $4.0(1.76)$ \\
\hline Wheat offal & $10.0(6.80)$ & $7.5(5.1)$ & $5.0(3.4)$ & $2.5(1.7)$ \\
\hline DBG & $6.0(4.32)$ & $6.0(4.32)$ & $6.0(4.32)$ & $6.0(4.32)$ \\
\hline DCP & $5.0(0.4)$ & $5.0(0.4)$ & $5.0(0.4)$ & $5.0(0.4)$ \\
\hline Table salt & 0.3 & 0.3 & 0.3 & 0.3 \\
\hline Total & $25 \mathrm{~kg}(\mathrm{CP}=13.3 \%)$ & $25 \mathrm{~kg}(\mathrm{CP}=13.34 \%)$ & $25 \mathrm{~kg}(\mathrm{CP}=13.40 \%)$ & $25 \mathrm{~kg}(\mathrm{CP}=13.46 \%)$ \\
\hline
\end{tabular}

Nb: PPLM, BDG and DCP imply Pueraria phaseoloides leaf meal, brewery dry grain and dry cassava peels, respectively.

Table $2.4 \times 4$ change-over Latin square design.

\begin{tabular}{|c|c|c|c|c|}
\hline $\begin{array}{l}\text { Trial acclimatization } \\
\text { Period } 1 \text { (1 week) }\end{array}$ & $\begin{array}{c}\text { Diet } 1 \\
\text { (WAD1) }\end{array}$ & Diet 2 (WAD2) & Diet 4 (WAD4) & Diet 3 (WAD3) \\
\hline Trial Period 1 (1 week) & $\begin{array}{c}\text { Diet } 1 \\
\text { (WAD1) }\end{array}$ & Diet 2 (WAD2) & Diet 4 (WAD4) & Diet 3 (WAD3) \\
\hline $\begin{array}{l}\text { Trial acclimatization } \\
\text { Period } 2 \text { (1 week) }\end{array}$ & Diet 1 (WAD3) & $\begin{array}{c}\text { Diet } 2 \\
\text { (WAD1) }\end{array}$ & Diet 4 (WAD2) & Diet 3 (WAD4) \\
\hline Trial Period 2 (1 week) & Diet 1 (WAD3) & $\begin{array}{c}\text { Diet } 2 \\
\text { (WAD1) }\end{array}$ & Diet 4 (WAD2) & Diet 3 (WAD4) \\
\hline $\begin{array}{c}\text { Trial acclimatization } \\
\text { Period } 3 \text { (1 week) }\end{array}$ & Diet 1 (WAD4) & Diet 2 (WAD3) & $\begin{array}{l}\text { Diet } 4 \\
\text { (WAD1) }\end{array}$ & Diet 3 (WAD2) \\
\hline Trial Period 3 (1 week) & Diet 1 (WAD4) & Diet 2 (WAD3) & $\begin{array}{c}\text { Diet } 4 \\
\text { (WAD1) }\end{array}$ & Diet 3 (WAD2) \\
\hline $\begin{array}{l}\text { Trial acclimatization } \\
\text { Period } 4 \text { (1 week) }\end{array}$ & Diet 1 (WAD2) & $\begin{array}{c}\text { Diet } 2 \\
\text { (WAD4) }\end{array}$ & Diet 4 (WAD3) & Diet 3 (WAD1) \\
\hline Trial Period 4 (1 week) & Diet 1 (WAD2) & $\begin{array}{c}\text { Diet } 2 \\
\text { (WAD4) }\end{array}$ & Diet 4 (WAD3) & Diet 3 (WAD1) \\
\hline
\end{tabular}

Nb: Diets 1, 23 and 4 contained Pueraria phaseoloides at 0\%, 10\%, 20\% and 30\% levels of inclusion.

their feed troughs. Between 07:00 and 07:30 hr the following morning, the remaining diets in the feed troughs were removed and weighed with the aid of a table or kitchen scale (Havana model) to determine daily concentrates' intake of each goat. The total daily intake was taken as the difference between quantity served between 07:30 and 08:00 hr and the quantity emptied from each feed trough before fresh feeds were served between 07:30 and 08:00 hr. The feeding trials comprised eight periods that were made up of equal number of weeks ( $\mathrm{n}=$ 4) shared between trial acclimatization and trial periods (Table 2).

\subsubsection{Live Weights}

The body weight measurements were first taken on the first day of the trial before the daily feeds were served; subsequent measurements taken on weekly basis throughout the study that lasted 12 weeks (four weeks of first acclimatization period inclusive).

\subsubsection{Blood Samplings}

On the last day of each trial period, between 07.00 and $08.00 \mathrm{hr}$, blood samples of all the goats were collected as described by [11] from the jungular vein into two $5 \mathrm{ml}$ pre-cooled heparinized and un-heparinized vacuum tubes (Becton Dickinson vacutainer systems, Europe). The blood samples were preserved in a plastic container containing ice blocks and taken to the Pathology Laboratory, University of Ilorin Teaching Hospital, Ilorin-Nigeria for analysis. 


\section{A. A. Akingbade et al.}

\subsection{Laboratory Analysis}

The experimental diets were subjected to proximate (crude protein (CP), crude fibre (CF), ether extractives (EE), ash and nitrogen free extractives (NFE)) analysis according to [12] procedures. The blood constituents analysed as described by [12] were: blood protein (total protein, albumin and globulin) and blood micro-mineral elements (iron, copper and zinc).

\subsection{Statistical Analysis}

The experimental data were subjected to analysis of variance (ANOVA) as described by [13]. Treatment means were compared using the standard error of the difference (s.e.d.) between means for significance $(p<0.05)$.

\section{Results and Discussion}

\subsection{Proximate and Energy Compositions of Experimental Diets}

Results of proximate and energy compositions analysis of the experimental diets are presented in Table 3; the range values of the diets CP (19.24\% and 20.12\%) revealed that the diets differed marginally in CP contents.

\subsection{Feed Intakes, Live Weights Changes, Blood Protein and Micro-Mineral Elements}

Feed intakes, live weights changes and haematological constituents' data are presented in Table 4; differences

Table 3. Proximate (\%) and energy contents (KCal/100g) of the experimental diets.

\begin{tabular}{ccccc}
\hline $\begin{array}{c}\text { Proximate/Energy } \\
\text { Analysis }\end{array}$ & $\begin{array}{c}\text { Diet 1 } \\
\text { (0\% PPLM) }\end{array}$ & $\begin{array}{c}\text { Diet 2 } \\
\text { (10\% PPLM) }\end{array}$ & $\begin{array}{c}\text { Diet 3 } \\
\text { (20\% PPLM) }\end{array}$ & $\begin{array}{c}\text { Diet 4 } \\
\text { (30\% PPLM) }\end{array}$ \\
\hline Moisture & 5.57 & 3.59 & 6.34 & 5.50 \\
CP & 20.11 & 20.12 & 19.24 & 19.24 \\
CF & 7.52 & 7.41 & 7.46 & 10.26 \\
EE & 3.80 & 2.03 & 3.69 & 9.34 \\
Ash & 9.30 & 15.44 & 8.26 & 11.56 \\
NFE & 53.73 & 51.42 & 55.02 & 44.11 \\
GE & 359.58 & 334.03 & 360.07 & 378.46 \\
\hline
\end{tabular}

Nb: CP, CF, EE, NFE, GE and PPLM imply crude protein, crude fibre, ether extractives, nitrogen free extractives, gross energy and Pueraria phaseoloides leaf meal, respectively.

Table 4. Feed intakes, live weight changes, blood proteins and micro-mineral elements of growing male WAD goats on diets containing varying levels of PPLM.

\begin{tabular}{cccccc}
\hline Parameters & $\begin{array}{c}\text { Diet 1 } \\
\text { (0\% PPLM) }\end{array}$ & $\begin{array}{c}\text { Diet 2 } \\
\text { (10\% PPL) }\end{array}$ & $\begin{array}{c}\text { Diet 3 } \\
\text { (20\% PPLM) }\end{array}$ & $\begin{array}{c}\text { Diet 4 } \\
\text { (30\% PPLM) }\end{array}$ & s.e.d. \\
\hline Feed intakes (kg/wk) & 1.020 & 0.620 & 0.236 & 0.606 & 0.35 \\
Live weight changes (kg/wk) & 0.125 & 0.050 & -0.375 & -0.425 & 0.67 \\
Blood proteins & & & & \\
Globulin & 29.55 & 26.36 & 40.23 & 33.65 & 40.53 \\
Albumin & 44.75 & 48.44 & 41.82 & 44.66 & 7.03 \\
Total protein & 74.30 & 74.79 & 82.05 & 78.31 & 7.29 \\
Blood micro elements & & & & 0.12 & 0.52 \\
Iron & 0.12 & 0.11 & 0.13 & 0.05 & 0.32 \\
Copper & 0.04 & 0.05 & 0.04 & 0.06 & 0.33 \\
\hline
\end{tabular}


between treatments for feed intakes and changes in live weights of the goats were not significant $(\mathrm{p}>0.05)$. However, goats on Diets 1 and 2 recorded positive weight changes with goats on Diet 1 having the highest positive weight change. The highest intake of goats on Diet 1 that lacked PPLM seems to suggest acceptability of the diet. Anti-nutrients limit the availability and utilization of nutrients by animals [14]. Previous study [15] revealed that Pueraria phaseoloides contains anti-nutrients such as tannins, phytate, oxalate, HCN and saponin; these anti-nutrients probably were responsible for the reduction in both intake and weight gain on diets containing PPLM. Feed intakes, live weight changes, blood protein and micro-mineral elements of the growing male WAD goats were unaffected by the dietary treatments imposed. Feed intake influences growth performance of animals [16]. The insignificance ( $>0.05$ ) recorded for changes in live weights of the WAD goats was expected because their feed intakes were not significantly different $(\mathrm{p}>0.05)$. [8] did report that protein contents of diets influence intake; the insignificance in voluntary feed intakes can be ascribed to the marginal difference in $\mathrm{CP}$ contents of the diets as revealed in the results of proximate analysis. This is consistent with the previous reports by [17] that diets that are marginally different in CP contents are unlikely to influence growth performance of animals significantly. Nutrition status influences blood protein constituents [8]. Similarly, the insignificance recorded for the blood protein constituents can also be attributed to the marginal difference in CP contents of the experimental diets.

\section{References}

[1] Wilson, L.L., Katsigianis, T.S., Dorsett, A.A. and Grave, A.G. (1980) Performance of Native and Anglo-Nubian Crosses and Observation on Improved Pastures for Goats in Bahamas. Tropical Agriculture of Trinidad, 57, $187-190$.

[2] Babayemi, O.J., Bamikole, M.A., Daniel, I.O., Ogangbesan, A. and Oduguwa, B.O. (2003) Growth and Dry Matter Degradability of Three Tephrosia Species in Nigeria. Journal Animal Production, 30, 62-70.

[3] Sowande, O.S., Aina, A.B.J., Oguntona, E.B., Fanimo, A.O., Unaka, V.U., Hassan, T.A. and Oseni, M.O. (2008) Performance, Blood Constituents and Mineral Balance of West African Dwarf Sheep Fed Preserved Elephant Grass, Layers Droppings and Cassava Peel Diets during Dry Season. Nigerian Journal of Animal Production, 35, 90-102.

[4] Hussein, H.I., Khalifa, S.F., Ghareeb, A. and Fawzi, N. (1989) Taxonomic Criteria of the Characteristic Features in Seeds of Some Selected Species of Caesalpinioideae-Leguminosae. Egyptian Journal of Biotechnology, 12, $280-298$.

[5] Cook, B., Pengelly, B., Brown, S., Donnelly, J., Eagle, D., Franco, J., Hanson, J., Mullen, B., Partridge, I., Peters, M. and Schultze-Kraft, R. (2005) Tropical Forages: An Interactive Selection Tool. CSIRO, DPI\&F (Qld), CIAT and ILRI, Brisbane. http://www.tropicalforages.info/

[6] Kerr, G.R., Lee, E.S., Lan, M.K.M., Lorimar, R.J., Randall, E. and Forthoter, R.N. (1982) Relationship between Dietary and Biochemical Measure of Nutritional Status. Amsterdam Journal of Clinical Nutrition, 35, 294-318.

[7] Olorede, B.R., Ajagborinla, O.P. and Babatunde, G.M. (1997) Comparison of Air-Dried and Oven-Dried Poultry Dropping in Broiler Rations. Effect on Performance and Haematological Parameters. International Journal of Animal Science, 10, 239-293.

[8] Akingbade, A.A. (2002) Productivity of South African Indigenous Nguni Goats Possessing Synergists Jonesii Bacteria on Leucaena leucocephala and Natural Pastures. PhD Thesis, University of Natal, Republic of South Africa.

[9] Ramprabhu, R., Chellapandian, M., Balachandran, S. and Jonhson, R.J. (2010) Influence of Age and Sex on Blood Parameters of Kanni Goats in Tamil Nadu. Indian Journal of Small Ruminant, 16, 84-89.

[10] Amao, S.R., Ojedapo, L.O. and Sosina, A.O. (2010) Effect of Strains on Some Growth Traits of Meat-Type Chickens Reared in Derived Savanna Environment of Nigeria. Journal of Agriculture and Veterinary Sciences, 2, 58-64.

[11] Van Niekerk, F.E., Cloete, S.W.P. and Barnard, S.A. (1990) Plasma Copper, Zinc and Blood Selenium Concentration of Sheep, Goats and Cattle. South African Journal of Animal Science, 20, 144-147.

[12] Association of Analytical Chemists (AOAC) (1990) Official methods of Analysis. 15th Edition, Washington DC.

[13] Steel, R.G.D. and Torrie, J.M. (1980) Principles and Procedures of Statistics: A Biometrical Approach. 2nd Edition, McGraw-Hill, New York, 633 p.

[14] Adesogan, A., Sollenbenger, L.E. and Moore, J.E. (2006) Feeding Value and Anti Nutritive Factors of Forage Tree Legume. Journal of Agronomy, 7, 174-179.

[15] Obua, B.B., Okocha, C.N. and Nwaoha, L.E. (2012) Proximate Composition and Anti-Nutritional Factors of Some Forage Species Used in Feeding Rabbits in Umudike Humid South Eastern Nigeria. International Journal of Agricultural and Rural Development. SAAT FUTO, 15, 1275-1286. 
[16] McDonald, P., Edward, R.A. and Greenhalgh, J.F.D. (1990) Voluntary Food Intake in Animal Nutrition. 4th Edition, Longman Scientific and Technical U.K, 375-397.

[17] Akingbade, A.A., Odunsi, A.A. and Ogunleke, O. (2000) Wild Sunflower (Tithonia diversifolia Hemsl. A. Gray) Leaf Meal as a Protein Supplement to Guinea Grass (Panicum maximum) in Feeding Young Female, West African Dwarf Goats in the Derived Savanna Zone of Nigeria. Tropical Animal Production and Investigation, 3, 145-149. 